\title{
A Review of Detection Methods for the Plant Viruses
}

\author{
*Co-corresponding author \\ Tel : +82-63-270-2519 \\ Fax: $+82-63-270-2531$ \\ E-mail: juhojong@jbnu.ac.kr \\ **Co-corresponding author \\ Tel : +82-63-290-6399 \\ Fax: +82-63-290-6398 \\ E-mail: nohjj@korea.kr
}

Received July 31, 2014

Revised September 2, 2014

Accepted September 4, 2014

\author{
Joo-jin Jeong ${ }^{1}$, Ho-jong Ju ${ }^{1,2 *}$ and Jaejong $\mathrm{Noh}^{3 * *}$ \\ ${ }^{1}$ Department of Agricultural Biology Chonbuk National University, Jeonju 561-756, Korea \\ ${ }^{2}$ Plant Medical Research Center Chonbuk National University, Jeonju 561-756, Korea \\ ${ }^{3}$ Watermelon Experiment Station, Jeollabuk-do Agricultural Research \& Extension Services, \\ Gochang 585-863, Korea
}

\begin{abstract}
The early and accurate detection of plant viruses is an essential component to control those. Because the globalization of trade by free trade agreement (FTA) and the rapid climate change promote the country-tocountry transfer of viruses and their hosts and vectors, diagnosis of viral diseases is getting more important. Because symptoms of viral diseases are not distinct with great variety and are confused with those of abiotic stresses, symptomatic diagnosis may not be appropriate. From the last three decades, enzyme-linked immunosorbent assays (ELISAs), developed based on serological principle, have been widely used. However, ELISAs to detect plant viruses decrease due to some limitations such as availability of antibody for target virus, cost to produce antibody, requirement of large volume of sample, and time to complete ELISAs. Many advanced techniques allow overcoming demerits of ELISAs. Since the polymerase chain reaction (PCR) developed as a technique to amplify target DNA, PCR evolved to many variants with greater sensitivity than ELISAs. Many systems of plant virus detection are reviewed here, which includes immunological-based detection system, PCR techniques, and hybridization-based methods such as microarray. Some of techniques have been used in practical, while some are still under developing to get the level of confidence for actual use.
\end{abstract}

Keywords : ELISA, PCR, Plant Virus Detection, Symptomatic diagnosis

\section{Introduction}

Generally speaking, viruses are very tiny compared to other groups of plant pathogens like fungi and bacteria which can be visualized through microscopes but plant viruses are too small to observe using light microscopes and they can be seen only using a transmission electron microscope and are made of a coat protein and a types of nucleic acid, DNA or RNA based on the nucleic acid core carrying genetic information (Ellis et al., 2008). Since Tobacco mosaic virus (TMV) was first recognized over a century ago, more than 1000 of plant viruses have been found (King et al., 2011; Scholthof, 2000). It has been known that like other plant pathogens including bacteria, fungi, and phytoplasma, plant viruses spread and cause major economic losses to many crops such as barley, corn, potato, rice, and wheat (Agrios, 2005; Ellis et al., 2008; Strange, 2005). Virus is ranked as the second most important plant pathogens following fungi (Vidaver and Lambrecht, 2004). Economic loss has been estimated more than several billions dollars per year worldwide

Research in Plant Disease

The Korean Society of Plant Pathology

pISSN 1598-2262, elSSN 2233-9191 because of plant viruses (Hull, 2002; Plant Viruses, 2003). Plant viruses cause the damage inside plant cells by intervening the allocation of resources that the plant has produced through photosynthesis.

The crop damages owing to viral diseases are difficult to predict, because it depends on region, virus strain, host plant cultivar/variety, and time of infection (Strange, 2005). Symptoms of viral diseases include crinkling, browning of leaf tissues, mosaic, and necrosis. Sometimes, however, symptoms may not be visually detected because infection of plant viruses causes no symptoms (Bove et al., 1988; van der Want and Dijkstra, 2006). In addition, plants can also display virus-like symptoms when plants respond to unfavorable weather, nutritional imbalances, infection by other types of pathogens mentioned above, damage caused by pests or abiotic agents and others (van der Want and Dijkstra, 2006). Thus, viral disease diagnosis by symptoms is more difficult than other pathogens (Lievens et al., 2005).

The diagnosis is the basis to manage plant diseases and to predict the crop loss by infection of plant pathogens (van der Want and Dijkstra, 2006). Accurate diagnosis of virus diseases, is the first important step for crop management system (Aboul-Ata et al., 2011). Since after virus infection, agrochemical treatments 
to plants do not lead to an effective control, viral diseases most effectively managed as control measures are applied before infection (Aboul-Ata et al., 2011). In order to prevent plant viral diseases, it is important to figure out the causes and to distinguish diseased plants and unaffected plants that show viruslike symptoms (Pearson et al., 2006).

As the internationalization of the domestic agricultural market, virus diagnostics is very essential to use high-quality seed as well as virus-free seeds (Lievens et al., 2005; Wang et al., 2011). As mentioned above, unlike other plant pathogens, the management of plant viral diseases based on direct methods have not been developed yet, so that viral diseases can be controlled by indirect strategies such as insect viral vector control or removing diseased plants (Aboul-Ata et al., 2011; Wang et al., 2011). The methods for detection and identification of viruses are critical in virus disease management (Aboul-Ata et al., 2011). Therefore, detection methods should be more convenient, effective, specific and permitted the use for detecting plant pathogens (McCartney et al., 2003).

A lot of methods have been developed to detect plant viruses, such as microscopical observation, serological techniques, molecular methods and so on (Lopez et al., 2008; Makkouk and Kumari, 2006; Webster et al., 2004). Among them, a number of methods for the diagnosis of plant viral diseases are reviewed in the following two sections, serological method and molecular method.

\section{Serological methods:}

Serological detection systems use specific antibody developed in animals in respond to antigens (Torrance, 1998). Viruses can be detected if viral antigens are used to develope antibody. In fact, these kinds of techniques have been used for the routine diagnostic tool. Many serological methods have been reported including enzyme-linked immunosorvent assay (ELISA), tissue blot immunoassay (TBIA) and quartz crystal microbalance immunosensors (QCMI).

ELISA. Common ELISAs are performed in polystyrene plate capable of binding antibodies or proteins with association of the enzyme-substrate reaction (Corning Life Science, 2001; Luminex, 2010). In order to get an accurate and reproducible result, the enzyme-substrate reaction needs to be optimized timing and development conditions (Corning Life Science, 2001). ELISA has been used as very popular assay to detect plant viruses within plant material, insect vectors, and seeds (Clark and Adams, 1977; Naidu and Hughes, 2001; Webster et al., 2004). Level of infection is measured based on the optical density (the degree of coloration) of ELISA reaction (Corning Life Science, 2001; Webster et al., 2004). Advantages of ELISA are that it is sensitive, a great number of samples can be examined at the same time (Vemulapati et al., 2014) little amount of antibody for the detection of diseases, and the process can be semiautomated (Naidu and Hughes, 2001). Specific antiserum has been developed against the target virus (Torrance, 1998). It has been employed for the detection of a lot of viruses including CMV, Citrus tristeza virus (CTV), Potato leaf roll virus (PLRV), Potato virus $X$ (PVX), and Potato virus Y (PVY) (El-Araby et al., 2009; Sun et al., 2001). Large amount of sample for ELISA is needed for capturing antigen of interest from the sample compared to sample requiring for molecular methods and it takes about 2 days for diagnosis (Lievens et al., 2005; Luminex, 2010). Since ELISA is antiboy-antigen based assay, availability of antibody properly responding against the target agent is regarded as very important factor. ELISA often offers misdiagnosis due to false positive which is mainly resulted from non-specific reactions or cross-reactivity with certain factors in samples (Kfir and Genthe, 1993). Antibody used in ELISA can respond to many strains with an obvious different symptom because of lack of specificity. Therefore, strains of virus very related cannot be differentiated correctly by ELISA (Boonham et al., 2014). Although ELISA sensitivity was increased by adding some additives in extraction buffer (Fegla and Kawanna, 2013), ELISA is generally less sensitive when compared to molecular methods. Because of these reasons, although ELISAs have been widely used for diagnostic purpose up to date, the use of ELISA in terms of diagnosis seems to be gradually decreased. It is thought that alternative tools to be employed in coming age will be introduced in to a diagnostic market or more researches will be continued to overcome ELISA's shortcomings.

Tissue blot immunoassay (TBIA). Since principle of TBIA is the same with that of ELISA to which antibody is applied, TBIA has the same reliability to ELISA to detect plant viruses (Hančević et al., 2012). Major difference is that polystyrene plate is used as platform of ELISAs, whereas TBIA is performed on nitrocellulose and nylon membranes. That is reason that this assay is called as TBIA or TIBA (Webster et al., 2004). Like ELISA, TBIA also has necessary of a specific antibody to get rid of false positive and also needs large amount of virus concentration to reduce false negative. However, since TBIA has great benefits over ELISA in terms of detection time, cost, sensitivity and convenience, it has been applied for diagnosis of a number of viral diseases caused by Bamboo mosaic virus (BoMV), Bean yellow mosaic virus (BYMV), CTV, Cymbidium mosaic virus (CyMV), Papaya ringspot virus (PRSV), Sweet potato feathery mottle virus (SPFMV), and Tomato spotted wilt virus (TSWV) (Bove et al., 1988; Eid et al., 2008; Hančević et al., 2012; Lin et al., 1990; Makkouk and Kumari, 2006; Shang et al., 2011; Webster et al., 2004).

Quartz crystal microbalance immunosensors (QCMI). The QCM measures mass based on vibrations and frequency change in real time and it has been widely used to measure small mass in vacuum, gas, and liquid condition (Kurosawa et al., 2006; Mecea, 2005, 2006). Immunological combination with QCM results in QCMI as a mass-sensitive transducer device (Owen et al., 2007). Antigen-antibody binding reaction causes decreased quartz crystal oscillation frequency in positive reaction. QCMI, which offers some advantages, including high 
sensitivity, real time output, portability, label-free entities, and low cost of operation, fabrication, and maintenance becomes attractive alternatives to conventional analysis methods (Chen and Tang, 2007; Lee and Chang, 2005; Tang et al., 2006). If the analytical signal is too weak to detect target materials, the detection sensitivity can be increased by introducing the signalenhancing step (Kurosawa et al., 2006). QCMI shows high detection sensitivity for biological materials even viruses (Bachelder et al., 2005; Eun et al., 2002; Kleo et al., 2011; Lee and Chang, 2005; Owen et al., 2007; Su et al., 2003; Susmel et al., 2000; Uttenthaler et al., 2001). Because a detection instrument for QCM is potable and QCM coated with virus-specific antibodies to detect plant viruses has long life span, it can be used for on site detection of plant viruses (Becker and Cooper, 2011; Eun et al., 2002).

Since QCM has proven to be successful in detection of plant viruses, including Cymbidium mosaic virus (CyMV), TMV and Turnip yellow mosaic virus (TYMV), were detected using QCM (Dickert et al., 2004; Eun et al., 2002; Zan et al., 2012).

\section{Molecular methods:}

Molecular methods can be applied for diagnosis of many viral diseases when genetic information of viruses is available. As an alternative method to serological one, it is most commonly used in the laboratory due to high accuracy and sensitivity.

\section{Polymerase chain reaction (PCR).}

PCR and reverse transcription PCR (RT-PCR). PCR is a scientific technique used to amplify, or create millions of identical copies of a particular DNA sequence within a tiny reaction tube. Prior to the initiation of each new round for DNA amplification, the DNA is denatured, two sets of oligonucleotides (called primers) anneal to the denatured complementary strand. Then, primers lead DNA synthesis by the DNA polymerase. All reactions occur sequentially in template dependent manner. Thorough this, the target sequences of interesting DNA are exponentially amplified (Saiki et al., 1985, 1988).

PCR has been used as one of core techniques to molecular biology based-researches in a many of applications such as cloning, gene manipulation, gene expression analysis, genotyping, sequencing, and mutagenesis. In addition, PCR has also been used as a diagnostic tool to detect diseases (Makkouk and Kumari, 2006; Schaad and Frederick, 2002).

Currently, PCR is popular techniques for detection of plant viruses in the laboratory and is very commonly used in molecular experiments (Webster et al., 2004). PCR is currently the basis of all diagnostic methods, used with other detection methods (Lopez et al., 2008). The effective diagnostic methods of viruses, PCR is able to process by the specificity of the primers. PCR is proceeded through three steps, denaturation above $94^{\circ} \mathrm{C}$, annealing of primers at $50-75^{\circ} \mathrm{C}$ (depend on primers) and elongation at $72^{\circ} \mathrm{C}$ (Makkouk and Kumari, 2006; McCartney et al., 2003).

RT-PCR used for the detection of RNA viruses requires reverse transcriptase which is added at the step of reverse transcription before the regular PCR step (Lopez et al., 2008; Webster et al., 2004). Since RT-PCR technique is sensitive, specific, and inexpensive compared to serological methods and is also more reliable than serological methods (Lievens et al., 2005; Lopez et al., 2008; McCartney et al., 2003), it has been developed and employed to detect many potato viruses such as PVX, PLRV, and PVS in stem or seeds of potato (Drygin et al., 2012; Ham, 2003; Peiman and Xie, 2006; Peter et al., 2009). Potato viruses within aphids, their vectors, can be detected by RT-PCR (Peter et al., 2009; Singh et al., 2004). In addition, RT-PCR to detect plant RNA viruses was used for quarantine purpose (Lee et al., 2011). This technique is able to detect five viruses not reported in Korea including Cucumber vein yellowing virus (CVYV), Cucurbit yellow stunting disorder virus (CYSDV), Potato aucuba mosaic virus (PAMV), Potato yellow dwarf virus (PYDV), and Tomato chlorosis virus (ToCV) (Lee et al., 2011).

Multiplex PCR. Two or more targets DNA or RNA can be detected at the same time via multiplex PCR in a single reaction (Lopez et al., 2008; Webster et al., 2004). This methods required several specific primers to detect over two viruses or bacteria ( $\mathrm{Li}$ et al., 2011; Menzel et al., 2002; Qu et al., 2011; Singh et al., 2000). There are several examples of simultaneous detection of viruses and also other plant pathogens in one host (Singh et al., 2000).

The many major characterized viruses were simultaneously detected at diseased apple trees through multiplex-PCR (Menzel et al., 2002). In comparison multiplex-PCR with ELISA to detect plant viruses, Apple chlorotic leafspot virus (ACLSV), Apple mosaic virus (ApMV), Prune dwarf virus (PDV), Prunus necrotic ringspot virus (PNRSV), and Plum pox virus (PPV), infection rate reported from multiplex-PCR was approximately $16.7 \%$ while ELISA was $10 \%$ although the same samples have been used, indicating that multiplex-PCR was superior to ELISA in time of detection and in sensitivity (Yardimic and Culal-KIllc, 2011). Mumford et al. (2000) employed fluorescence to detect multiple viruses in real time. Despite this benefit, conventional PCR is used more than multiplex PCR, probably due to the technical difficulties of reaction mixture involving many compatible primers (Lopez et al., 2008). Moreover, it is difficult to design specific primer for each target DNA and to distinguish with the difference DNA amplification of each size of the gene (Lopez et al., 2008; Webster et al., 2004).

Nested PCR. The method is useful when the virus titre is very low, target gene is unstable, and can not be checked by electrophoresis due to low amplification product (Webster et al., 2004). The product from primary PCR amplification is used for second PCR amplification. However, the second reaction can be caused to face the risk of contamination (Lopez et al., 2008). Problems mentioned above can be solved by Nested PCR (Olmos et al., 1999). Several viruses, including PNRSV, PDV, PPV and CTV, were detected by this technique (Adkar-Purushothama et al., 2011; Helguera et al., 2001, 2002; Olmos et al., 1999). This nested PCR was combine with Immunocapture-RT PCR to increase sensitivity and to simplify preparation of sample 
(Helguera et al., 2001, 2002). This method was applied to detect Lettuce mosaic virus (LMV) even in single aphids (Moreno et al., 2007).

Co-operational PCR (Co-PCR). Both co-operational PCR and nested-PCR require a tetra primer set (Olmos et al., 1999; Olmos et al., 2002). However, co-operational PCR needs one external and three internal primers instead of two external and two internal primers associated with nested-PCR (Olmos et al., 2002; Pantaleo et al., 2001). Since co-operational PCR uses four primers like nested-PCR, this technique has some benefits over conventional PCR (Lopez et al., 2008; Olmos et al., 2002). Benefits include a single reaction, minimization of contamination risks, high sensitivity similar to nested PCR, detection in real-time, and capability of coupling with dot blot hybridization (Bertolini et al., 2007; Lopez et al., 2008; Martos et al., 2011). In addition, Co-operational PCR can avoid false positive shown at nestedPCR (Olmos et al., 2002) and also can be applied to capillary air thermal cyclers which could not be applied for nest-PCR used to detect Squash vein yellowing virus (SqVYV) (Adkins et al., 2008).

Consequently, co-operational PCR needs less time than nested-PCR (Olmos et al., 2002). The major obstacle to use conventional PCR is existence of PCR inhibitors. This problem can be overcome by co-PCR with diluted samples. Undiluted samples showed a weak product by co-PCR whereas diluted samples gave better signal (Capote et al., 2009; Caruso et al., 2003). According to the detection of Cherry leafroll virus (CLRV), the sensitivity of co-PCR observed in virus detection is at least 100 times higher than RT-PCR and is similar with that of nested RT-PCR (Olmos et al., 2002). However, it is worthy to note that not all coPCR showed higher sensitivity compared to RT-PCR (Capote et al., 2009).

Real-time PCR. Real-time PCR was developed as one of the technical methods to monitor the amplification products of PCR in real-time and also allows accurate quantification of PCR products (McCartney et al., 2003; Ruiz-Ruiz, 2009). Real-time PCR can be dramatically reduced detection time and can be used for small concentration of target gene making possible to diagnose (Heid et al., 2011; Lopez et al., 2008) because of no need the gel elcetrophoresis for the confirmation. It also has been known that it is faster than conventional PCR with less risk of contamination (Lopez et al., 2008). Although the real time monitoring curve was raised up as the DNA exponentially amplified, there are some drawbacks to use real-time PCR. One is that the amplification arrests when it reaches certain level, plateau (Gibson et al., 1996). Other disadvantage is that real-time method requires highly expensive equipment. Though these demerits, real-time PCR has been increasingly used because this method has been showed valuable detection for plant viruses (McCartney et al., 2003). Citrus tristeza virus (CTV) in different plant tissues and TMV in soil were detected by real-time PCR and quantified Citrus leaf blotch virus (CLBV) (Ruiz-Ruiz et al., 2007, 2009; Yang et al., 2012). It also used to discriminate two potato pathogenic bacteria on infected potato tubers (Qu et al., 2011).

\section{Isothermal amplification.}

Generally speaking, the use of PCR variants is increasing for the disease diagnosis. In order to complete the first round of $\mathrm{PCR}, \mathrm{PCR}$ is necessary of 3 different temperatures for denaturalization of double stranded DNA, primer annealing to target DNA, and extension of DNA synthesis. Thus it needs expensive instruments that can control temperature precisely. Polymerase, which can amplify DNA, at constant temperature was discovered. It called Isothermal PCR. Many isothermal PCRs exist but here nucleic acids sequence-based amplification (NASBA) and loop-mediated isothermal amplification (LAMP) are described.

Nucleic acids sequence-based amplification (NASBA). NASBA, a primer-dependent continuous amplification, has been used for the direct amplification of RNA by PCR using a reverse transcriptase, RNase H and, T7 RNA polymerase (Compton, 1991). One of differences compared to conventional PCR is that it works at isothermal condition instead of thermal cycling. The other is that products by NASBA are antisense to the target viral sequences. Lopez et al. (2008) carried out the entire process at $41^{\circ} \mathrm{C}$ for $60 \mathrm{~min}$ and visualized a real-time assay using molecular beacons.

Since it is more sensitive than conventional PCR, the reaction time can be reduced (Vaskova et al., 2004). Real-time NASBA has been applied to detect plant viruses including Strawberry vein banding virus (SVBV), Apple stem pitting virus (ASPV) and PPV (Klerks et al., 2001; Leone et al., 1997; Olmos et al., 2007; Vaskova et al., 2004).

Loop-mediated isothermal amplification (LAMP). LAMP is performed at a constant temperature for one hour using the four primers (Notomi et al., 2000). The first product is formed in the loop formation and DNA has incessantly amplified from the first products resulted in various sized DNA structures (Fig. 1). The diagnosis, therefore, is possible although there is very small amounts of target gene (Parida et al., 2008; Tomita et al., 2008). The LAMP products from reaction can be detected by electrophoresis and observed a smear of multiple bands in a lane of positive LAMP reaction (Notomi et al., 2000; Parida et al., 2008; Tomita et al., 2008).

The LAMP assay has been recently applied for the rapid detection of several viruses in animal, such as Canine parvovirus (Cho et al., 2006). In addition, it has been used to determine sex of asparagus, genetically modified organisms (GMOs), and Phytoplasmas (Lee et al., 2009; Shiobara et al., 2011; Tomlinson, 2010). The RT-LAMP has been developed for simple monitoring of RNA viruses including PVY and PLRV (Ju, 2011; Nie, 2005).

\section{Microarray (Oligonucleotide array).}

Microarray is the evolved platform of the southern blotting technology. This technique used glass instead of nitrocellulose and nylon membrane as a supporter (Maskos and Southern, 

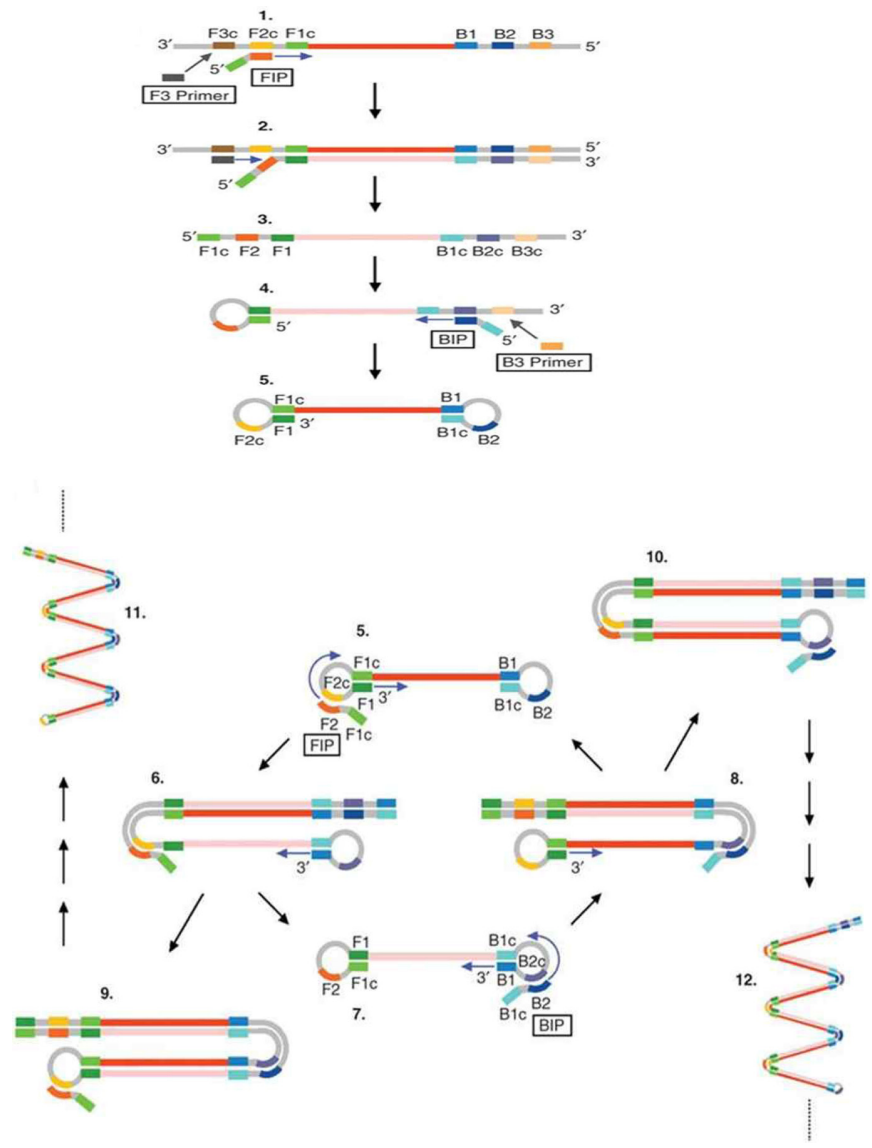

Fig. 1. Principle of LAMP-PCR. While DNA denaturation step (the double stranded DNA into a single strand) is vital for conventional PCR, LAMP-PCR does not require that. There are 11 steps for LAMP-PCR. 1, After FIP (one of the LAMP primers) anneals to the complimentary sequence of target DNA conditioned around $65^{\circ} \mathrm{C}$, DNA strand is synthesized from the $3^{\prime}$ end of the F2 in the FIP by DNA polymerase with strand displacement activity; 2 , The F3 anneals to the F3c region on the target DNA and begins releasement of FIP-linked complementary strand synthesized at step $1 ; 3-4$, The released single strand forms a loop structure at the $5^{\prime}$ end because the F1c is complementary to F1 and after BIP anneals to its complimentary, new DNA strand is synthesized from the 3 ' end of the B2 in the BIP by DNA polymerase; 5 , The $B 3$ anneals to the $B 3$ c region, outside of $B I P$, on the target DNA and begins synthesis of DNA strand (BIP-linked complementary strand), forming dumbell-like structure with stem-loop at each end due to complimentary of $\mathrm{F} 1$ and $\mathrm{B} 1$ to $\mathrm{F} 1 \mathrm{C}$ and $\mathrm{B} 1 \mathrm{c}$, respectively. This structure serves as the starting material for the amplification; 6-12, FIP anneals to the stem-loop DNA and leads strand displacement DNA synthesis and, releasing the previously synthesized strand which forms a stem-loop structure at the $3^{\prime}$ end owing to B1c is complementary to B1. Later complementary strand with FIP is released. The released strand forms dumbbell-like structure with stem-loop at each end since $\mathrm{F} 1$ and $\mathrm{B} 1$ are complimentary to $\mathrm{F} 1 \mathrm{C}$ and B1C, respectively. Because DNA synthesis continues, there are various sized structures (Under permission form Eiken Chemical Co, Ltd. 2005; Eiken, 2005).

1992) and was initially developed for differentiation of messenger RNA expression (Schena et al., 1995). Later, this technique demonstrated the potential to detect viral pathogens without amplification of viral RNA (Nam et al., 2014). Oligochips used in oligonucleotide array is composed of thousands of specific probes spotted onto a solid surface like a glass plate (Lopez et al., 2008). Synthesized single stranded DNA probes with about $25 \mathrm{bp}$ to $70 \mathrm{bp}$ nucleotides are hybridized with the virus extracted from plant (Lee et al., 2003; Wang et al., 2002, 2003). Most drawback is cost since it requires the highly sophisticated processing machine for spotting probes and reading reactions and also needs dust-free room (Wang et al., 2002). The other problem is construction of oligonucleotide to be hybridized to target DNAs in terms of specificity and sensitivity (Dugat-Bony et al., 2012). Because of those, it has not been widely used and is still under research phase. However, some trials to use this method can be found because it is able to detect both known and unknown sequences in environmental samples, resulted in identifying unknown viruses by Oligo-chip (Boonham et al., 2007; Dugat-Bony et al., 2012; Nam et al., 2014; Schena et al., 1995). This method was used detection for potato viruses such as Potato virus $A$ (PVA), Potato virus M (PVM), Potato virus $S$ (PVS), PVX, PVY and PLRV and cucurbit-infecting plant viruses (Bystricka et al., 2005; Lee et al., 2003). It is also able to identify any plant virus at the genus level and can differentiate relevant strains (Hammond, 2011; Wang et al., 2002; 2003; Zhang et al., 2010). Recently, a large-scale oligonucleotide (LSON) chip were developed to detect and to identify 538 plant viruses (Nam et al., 2014). Since this method has the great potential to detect all the pathogen in animals and human beings, and plants in a single chip, it can be extended for quarantine purposes.

\section{Conclusions}

Economic loss has been estimated more than several billion dollars per year worldwide due to plant viral diseases and there is no commercialized chemical to manage those. Plant diseases caused by viruses can be effectively controled when means of manage are applied at the initial step of viral disease development or by planting virus-free crops. This is reason why accurate diagnosis is important. Symptomatic diagnosis is still useful but often has erroneous results, because of confusion associated with high variable symptoms by interactions between host and virus or by abiotic stresses. Therefore, reliable diagnostic platforms which can be accepted officially are required.

The methods based on serological principle and molecular biology have been used for virus diagnosis. ELISA associated with serology was initiated and adapted as a diagnostic tool worldwide since it is easy to use with durability. After PCR invented, PCR based diagnostics have been adapted as a diagnostic system comparable with ELISA even becoming predominant method. There are several reasons for this change. PCR is standardized in industrial level as ELISA resulting in worldwide use in diagnostic facilities. Futhermore, PCR-based assay has better sensitivity over ELISA and even faster. Isothermal nucleic acid amplification methods including LAMP are under development for virus detection because it is faster and has greater sensitivity 
over conventional PCR. Although microarray invented to examine variations in level of messenger RNA expression is still under research phase to increase sensitivity for differentiating target signal with background due to host, which is one of drawback for microarray compared to PCR method, it has been showed highly potential to use as a diagnostic tool.

Many kinds of techniques are available now and are developing for the diagnostic purpose. Since there is no an ideal detection method to fulfil all requirement to detect, it is very important to develop appropriate and effective techniques which can be applied for management of viral diseases in worldwide level. By doing that sustainable agriculture will be achieved.

\section{Acknowledgement}

This work was supported by a Grant from the Next-Generation Biogreen 21 Program (PJ008063), Rural Development Administration, Republic of Korea.

\section{References}

Aboul-Ata, A. E., Mazyad, H., El-Attar, A. K., Soliman, A. M., Anfoka, G., Zeidaen, M., Gorovits, R., Sobol, I. and Czosnek, H. 2011. Diagnosis and control of cereal viruses in the Middle East. Adv. Virus Res. 81: 33-61.

Adkar-Purushothama, C. J., Maheshwar, P. K., Sano, T. and Janardhana, G. R. 2011. A sensitive and reliable RT-nested PCR assay for detection of Citrus tristeza virus from naturally infected citrus plants. Curr. Microbiol. 62: 1455-1459.

Adkins, S., Webb, S. E., Baker, C. A., Baker, C. A. and Kousik, C. S. 2008. Squash vein yellowing virus detection using nested polymerase chain reaction demonstrates that the Cucurbit weed Momordica charantia is a reservoir host. Plant Dis. 92: 1119-1123.

Agrios, G. N. 2005. Plant Pathology. 5th ed. Elsvier, New York, NY. $922 \mathrm{pp}$.

Bachelder, E., Ainslie, K. and Pishko, M. 2005. Utilizing a quartz crystal microbalance for quantifying $\mathrm{CD}_{4}{ }^{+}$Tcell counts. Sensor Lett. 3: 211-215.

Becker, B. and Cooper, M. A. 2011. A survey of the 2006-2009 quartz crystal microbalance biosensor literature. J. Mol. Recognit. 24: 754-787.

Bertolini, E., Torres, E., Olmos, A., Martin, M. P., Bertaccini, A. and Cambra, M. 2007. Co-operational PCR coupled with dot blot hybridization for detection and 16SrX grouping of phytoplasmas. Plant Pathol. 56: 677-682.

Boonham, N., Kreuze, J., Winter, S., Van der Vlugt, R., Bergervoet, J., Tomilinson, J. and Mumford, R. 2014. Methods in virus diagnostics: From ELISA to next generation sequencing. Virus Res. 186: 2031.

Boonham, N., Tomilinson, J. and Mumford, R. 2007. Microarrays for Rapid Identification of Plant Viruses. Annu. Rev. Phytopathol. 45: 307-328.

Bove, J. M., Vogel, R., Albertini, D. and Bove, J. M. 1988. Discovery of a strain of Tristeza virus $(\mathrm{K})$ inducing no symptoms in Mexican lime. Proceedings of the 10th Conference of IOCV. Spain 1988.
International Organization of Citrus Virologists Riverside, CA. pp. 14-16.

Bystricka, D., Lenza, O., Mraza, I., Piherovad, L., Kmochd, S. and Sipc, M. 2005. Oligonucleotide-based microarray: A new improvement in microarray detection of plant viruses. J. Virol. Methods 128: 176-182.

Capote, N., Bertolini, E., Olmos, A., Vidal, E., Martinez, M. C. and Cambra, M. 2009. Direct sample preparation methods for the detection of Plum pox virus by real-time RT-PCR. Int. Microbiol. J. 12: 1-6.

Caruso, P., Bertolini, E., Cambra, M. and Lopez, M. M. 2003. A new and sensitive Co-operational polymerase chain reaction (Co$\mathrm{PCR}$ ) for a rapid detection of Ralstonia solanacearum in water. J. Microbiol. Methods 55: 257-272.

Chen, Z.-G. and Tang, D.-Y. 2007. Antigen-antibody interaction from quartz crystal microbalance immunosensors based on magnetic $\mathrm{CoFe}_{2} \mathrm{O}_{4} / \mathrm{SiO}_{2}$ compositenanoparticle-functionalized biomimetic interface. Bioproc. Biosyst. Eng. 30: 243-249.

Cho, H., Kang, J. and Park, N. 2006. Detection of canine parvovirus in fecal samples using loop-mediated isothermal amplification. J. Vet. Diagn. Invest. 18: 81-84.

Clark, M. F. and Adamas, A. N. 1977. Characteristic of the microplate of enzyme-linked immunosorbent assay for the detection of plant viruses. J. Gen. Virol. 34: 475-483.

Compton, J. 1991. Nucleic acid sequence-based amplification. Nature 350: 91-92.

Corning Life Science. 2001. Selecting the detection System: Colorimetric, Fluorescent, Luminescent Methods. ELISA Technical Bulletin 5:p14 http:// catalog2.corning.com/ Lifesciences/media/pdf/ elisa5.pdf (Accessed Jul. 24, 2014).

Dickert, F. L., Hayden, O., Bindeus, R., Mann, K., Blaas, D. and Waigmann, E. 2004. Bioimprinted QCM sensors for virus detection screening of plant sap. Anal. Bioanal. Chem. 378: 1929-1934.

Drygin, Y. F., Blintsov, A. N., Grigorenko, V. G., Andreena, I. P., Opsipov, A. P., Varitzev, Y. A., Uskov, A. I., Kravchenko, D. V. and Atabekov, J. G. 2012. Highly sensitive field test lateral flow immunodiagnostics of PVX infection. Appl. Microbiol. Biotechnol. 93: 179-189.

Dugat-Bony, E., Peyretaillade, E., Parisot, N., Biderre-Petit, C., Jaziri, F., Hill, D., Rimour, S. and Peyret, P. 2012. Detecting unknown sequences with DNA microarrays : explorative probe design strategies. Environ. Microbiol. 14: 356-371.

Eid, S., Atamian, H. S., Abou-Jawdah, Y. and Havey, M. J. 2008. Assessing the movement of Cucurbit yellow stunting disorder virus in susceptible and tolerant cucumber germplasms using serological and nucleic acid based methods. J. Phytopathol. 156: 438-445.

Eiken Chemical Co. Ltd. 2005. The principle of LAMP method. http://loop amp.eiken.co.jp/e/lamp/principle.html (Accessed Jul. 24, 2014).

El-Araby, S. W., Ibrahin, A. I., Hemeida, A. A., Mahmo, A., Soliman, M. A., El-Attar, K. A. and Mazyad, M. H. 2009. Biological, serological and molecular diagnosis of three major potato viruses in egypt. Int. J. Virol. 5: 77-88.

Ellis, S. D., Boehm, M. J. and Qu, F. 2008. Agriculture and Natural Resources: Viral Diseases of Plants (PP401.05) [Fact Sheet]. Ohio State Univ., Ohio State Univ. Extension. http://ohioline.osu.edu/ hyg-fact/3000/pdf/PP401_05.pdf (Accessed Jul. 24, 2014). 
Eun, A. J., Huang, L., Chew, F., Li, S. F. and Wong, S. 2002. Detection of two orchid viruses using quartz crystal microbalance (QCM) immunosensors. J. Virol. Methods 99: 71-79.

Fegla, G. and Kawanna, M. 2013. Improved indirect ELISA for detection of some plant viruses. Int. J. Agric. Biol. 15: 939-944.

Gibson, U. E. M., Heid, C. A. and Williams, P. M. 1996. A novel method for real time quantitative RT-PCR. Genome Res. 6: 995-1001.

Ham, Y. I. 2003. Review on the occurrence and studies of potato viral diseases in Korea. Res. Plant Dis. 9: 1-9.

Hammond, J. 2011. Universal plant virus microarrays, broad spectrum PCR assays, and other tools for virus detection and identification. Acta Hortic. 901: 49-60.

Hančević, K., Černi, S., Radić, T. and Škorić, D. 2012. Comparison of different methods for Citrus tristeza virus detection in Satsuma mandarins. J. Plant Dis. Protect. 119: 2-7.

Heid, C. A., Stevens, J., Livak, K. J. and Williams, M. P. 2011. Real time quantitative PCR. Genome Res. 6: 986-994.

Helguera, P. R., Docampo, D. M., Nome, S. F. and Ducasse, D. A. 2002. Enhanced detection of Prune dwarf virus in peach leaves by immunocapture-reverse transcription-polymerase chain reaction with nested polymerase chain Reaction (IC-RT-PCR Nested PCR). J. Phytopathol. 150: 94-96.

Helguera, P. R., Taborda, R., Docampo, D. M. and Ducasse, D. A. 2001. Immunocapture reverse transcription-polymerase chain reaction combined with nested PCR greatly increases the detection of Prunus necrotic ring spot virus in the peach. J. Virol. Methods 95: 93-100.

Hull, R. 2002. Matthew's Plant Virology. 4th ed. Academic Press, New York, NY. 1001 pp.

Ju, H.-J. 2011. Simple and rapid detection of Potato leafroll virus (PLRV) by reverse transcription loop-mediated isothermal amplification (RT-LAMP). Plant Pathology J. 27: 1-4.

Kfir, R. and Genthe, B. 1993. Advantages and disadvantages of the use of immunodetection techniques for the enumberation of microorganisms and toxins in water. Water Sci. Technol. 27: 243252.

King, A. M. Q., Adams, M. J., Eric, B. C. and Lefkowitz, E. J. 2011. Virus Taxonomy: Ninth Report of the International Committee on Taxonomy of Viruses. Elsevier. San diego, CA. 1339 pp.

Kleo, K., Kapp, A., Ascher, L. and Lisdat, F. 2011. Detection of vaccinia virus DNA by quartz crystal microbalance. Anal. Biochem. 418: 260-266.

Klerks, M. M., Leone, G., Lindner, J. L., Schoen, C. D. and ven den Heuvel, J. F. 2001. Rapid and sensitive detection of Apple stem pitting virus in apple trees through RNA amplification and probing with fluorescent molecular beacons. Phytopathology 91: 1085-1091.

Kurosawa, S., Park, J.-W., Aizawa, H., Wakida, S.-I., Tao, H. and Ishihara, K. 2006. Quartz crystal microbalance immunosensors for environmental monitoring. Biosens Bioelectron. 22: 473-481.

Lee, D., Mura, L. M., Alnutt, R. T. and Powell, W. 2009. Detection of genetically modified organisms (GMOs) using isothermal amplification of target DNA sequences. BMC Biotechnol. 9: 1-7.

Lee, G. P., Min, B. E., Kim, C. S., Choi, S. H., Harn, H. H., Kim, S. U. and Ryu, K. H. 2003. Plant virus cDNA chip hybridization for detection and differentiation of four cucurbit-infecting Tobamovi- ruses. J. Virol. Methods 110: 19-24.

Lee, J.-S., Cho, W. K., Lee, S.-H., Choi, H.-S. and Kim, K. H. 2011. Development of RT-PCR based method for detecting five non-reported quarantine plant viruses infecting the family Cucurbitaceae or Solanaceae. Plant Pathology J. 27: 93-97.

Lee, Y. G. and Chang, K. S. 2005. Application of a flow type quartz crystal microbalance immunosensor for real time determination of cattle bovine ephemeral fever virus in liquid. Talanta 65: 1335-1342.

Leone, G., van Schijndel, H. B., van Genien, B. and Schoen, C. D. 1997. Direct detection of Potato leafroll virus in potato tubers by immunocapture and the isothermal nucleic acid amplification method NASBA. J. Virol. Methods 66: 19-27.

Li, M., Asano, T., Suga, H. and Kageyama, K. 2011. A multiplex PCR for the detection of Phytophthora nicotianae and P. cactorum, and a survey of their occurrence in strawberry production areas of Japan. Plant Dis. 95: 1270-1278.

Lievens, B., Grauwet, T. J. M. A., Cammue, B. P. A. and Thomma, B. P. H. J. 2005. Recent developments in diagnostics of plant pathogens: a review. Recent Res. Dev. Microbiol. 9: 57-79.

Lin, N. S., Hsu, Y. H. and Hsu, H. T. 1990. Immunological detection of plant viruses and a mycoplasma like organism by direct tissue blotting on nitrocellulose membranes. Phytopathology 80: 824828.

Lopez, M. M., Llop, P., Olmos, A., Marco-Noales, E., Cambra, M. and Bertolini, E. 2008. Are molecular tools solving the challenges posed by detection of plant pathogenic bacteria and viruses? Curr. Issues Mol. Biol. 11: 13-45.

Luminex. 2010. xMAP Technology Technical Note: Overcoming the cost and performance limitations of ELISA with XMAP technology. http://www.luminexcorp.com/prod/ groups/public/documents/lmnxcorp/308-xmap-vs.-elisa-white-paper.pdf (Accessed Jul. 22, 2014).

Makkouk, K. M. and Kumari, S. G. 2006. Molecular diagnosis of plant viruses. Arab. J. Plant Protect. 24: 135-138.

Martos, S., Torres, E., El Bakali, M. A., Raposo, R., Gramaje, D., Armengol, J. and Luque, J. 2011. Co-operational pcr coupled with dot blot hybridization for the detection of Phaeomoniella chlamydospora on infected grapevine wood. J. Phytopathol. 159: 247-254.

Maskos, U. and Southern, E. M. 1992. Oligonucleotide hybridizations on glass supports: a novel linker for oligonucleotide synthesis and hybridization properties of oligonucleotides synthesised in situ. Nucleic Acids Res. 20: 1679-1684.

McCartney, A. H., Foster, S. J., Fraaige, B. A. and Ward, E. 2003. Molecular diagnostics for fungal plant pathogens. Pest Manag. Sci. 59: 129-142.

Mecea, V. M. 2005. From quartz crystal microbalance to fundamental principles of mass measurements. Anal. Lett. 38: 753-767.

Mecea, V. M. 2006. Is quartz crystal microbalance really a mass sensor? Sens. Act. A 128: 270-277.

Menzel, W., Jelkmann, W. and Maiss, E. 2002. Detection of four apple viruses by multiplex RT-PCR assays with coamplification of plant mRNA as internal control. J. Virol. Methods 99: 81-92.

Moreno, A., Bertolini, E., Olmos, A., Cambra, M. and Fereres, A. 2007. Estimation of vector propensity for Lettuce mosaic virus based 
on viral detection in single aphids. Span. J. Agric. Res. 5: 376384.

Mumford, R. A., Walsh, K., Barker, I. and Boonham, N. 2000. Detection of Potato moptop virus and Tobacco rattle virus using a multiplex real-time fluorescent reverse transcription polymerase chain reaction assay. Phytopathology 90: 448-453.

Naidua, R. A. and Hughes, J. A. 2001. Methods for the detection of plant virus diseases. In: Proceedings of a Conference Organized by IITA, Plant Virology in Sub Saharan Africa pp. 233-260. International Institute of Tropical Agriculture. Oyo State, Nigeria.

Nam, M., Kim, J. S., Lim, S. M., Park, C. Y., Kim, J. G., Choi, F. S., Lim, H. S., Moon, J. S. and Lee, S. H. 2014. Development of the large-scale oligonucleotide chip for the diagnosis of plant viruses and its praclical use. Plant Pathology J. 30:51-57.

$\mathrm{Nie}, \mathrm{X} .2005$. Reverse transcription loop-mediated isothermal amplification of DNA for detection of Potato virus Y. Plant Dis. 89: 605-610.

Notomi, T., Okayama, H., Masubuchi, H., Yonekawa, T., Watanabe, K., Amino, N. and Hase, T. 2000. Loop-mediated isothermal amplification of DNA. Nucleic Acids Res. 28:e63 doi: 10.1093/nar/28.12. e63.

Olmos, A., Bertolini, E. and Cambra, M. 2002. Simultaneous and cooperational amplification (Co-PCR): a new concept for detection of plant viruses. J. Virol. Methods 106: 51-59.

Olmos, A., Bertolini, E. and Cambra, M. 2007. Isothermal amplification coupled with rapid flow-through hybridisation for sensitive diagnosis of Plum pox virus. J. Virol. Methods 139: 111-115.

Olmos, A., Cambra, M., Esteban, O., Gorris, M. T. and Terrada, E. 1999. New device and method for capture, reverse transcription, and nested PCR in a single closed-tube. Nucleic Acid Res. 27: 15641565.

Owen, T. W., Al-Kaysi, R. O., Bardeen, C. J. and Cheng, Q. 2007. Microgravimetric immunosensor for direct detection of aerosolized influenza A virus particles. Sens. Act. B 126: 691-699.

Pantaleo, V., Saponari, M. and Gallitelli, D. 2001 Development of a nested PCR protocol for detection of olive-infecting viruses in crude extracts. J. Plant Pathol. 83: 143-146.

Parida, M., Sannarangaiah, S., Dash, P. K., Rao, P. V. L. and Morita, K. 2008. Loop mediated isothermal amplification (LAMP); a new generation of innovative gene amplification technique; perspectives in clinical diagnosis of infectious diseases. Rev. Med. Virol. 18: 407-421.

Pearson, M. N., Clover, G. R. G., Guy, P. L., Fletcher J. D. and Beever, R. E. 2006. A review of the plant virus, viroid and mollicute records for New Zealand. Australas. Plant Pathol. 35: 217-252.

Peiman, M. and Xie, C. 2006. Sensitive detetction of potato viruses, PVX, PLRV, and PVS, by RT-PCR in potato leaf and tuber. Australas. Plant Dis. Notes 1: 41-46.

Peter, K. A., Gildow, F., Palukaitis, P. and Gray, S. M. 2009. The C terminus of the Polerovirus $\mathrm{P} 5$ readthrough domain limits virus infection to the phloem. J. Virol. 83: 5419-5429.

Plant Viruses. 2003. World of Microbiology and Immunology. http:// www.encyclopedia.com/doc/1G2-3409800449.html (Accessed Jul. 20, 2014)

Qu, X. S., Wanner, L. A. and Christ, B. J. 2011. Multiplex real-time PCR (TaqMan) assay for the simultaneous detection and discrimina- tion of potato powdery and common scab diseases and pathogens. J. Appl. Microbiol. 110: 769-777.

Ruiz-Ruiz, S., Ambros, S., del Carmen Vives, M., Navarro, L., Moreno, P. and Jose, G. 2009. Detection and quantitation of Citrus leaf blotch virus by TaqMan real-time RT-PCR. J. Virol. Methods 160: 57-62.

Ruiz-Ruiz, S., Moreno, P., Jose, G. and Ambros, S. 2007. A real-time RT-PCR assay for detection and absolute quantitation of Citrus tristeza virus in different plant tissues. J. Virol. Methods 145: 96105.

Saiki, R., Gelfand, D., Stoffel, S., Scharf, S., Higuchi, R., Horn, G., Mullis, K. and Erlich, H. 1988. Primer-directed enzymatic amplification of DNA with a thermostable DNA polymerase. Science 239: 487-491.

Saiki, R. K., Scharf, S., Falcona, F., Mullis, K., Horn, G. T., Erlich, H. A. and Arnheim, N. 1985. Enzymatic amplification of beta-globin genomic sequences and restriction site analysis for diagnosis of sickle cell anemia. Science 230: 1350-1354.

Schaad, N. W. and Frederick, R. D. 2002. Real-time PCR and its application for rapid plant disease diagnostics. Can. J. Plant Pathol. 24: 250-258.

Schena, M., Shalon, D., Davis, R. W. and Brown, P. O. 1995. Quantitative monitoring of gene expression patterns with a complementary DNA microarray. Science 270: 467-470.

Scholthof, K.-B. G. 2000. Tobacco mosaic virus. The Plant Health Instructor. http://www.apsnet.org/edcenter/intropp/lessons/ viruses/Pages/Tob accoMosaic.aspx (Accessed Jul. 20, 2014).

Shang, H., Xie, Y., Zhou, X., Qian, Y. and Wu, J. 2011. Monoclonal antibody-based serological methods for detection of Cucumber green mottle mosaic virus. Virol. J. 8: 228-234.

Shiobara, Y., Yoshino, M., Uragami, A., Widiastuti, A., Omori, A., Kuba, K., Saito, H., Hirata, Y., Sonoda, T., Koizumi, T. and Sato, T. 2011. Sex distinction of asparagus by loop-mediated isothermal amlification and observation of seedling phenotypes. Euphytica 177: 91-97.

Singh, P. R., Dilworth, D. A., Singh, M. and McLaren, L. D. 2004. Evaluation of simple membrane-based nucleic acid preparation protocol for RT-PCR detection of potato viruses from aphid and plant tissues. J. Virol. Methods 121:163-170.

Singh, R. P., Nie, X. and Singh, M. 2000. Duplex RT-PCR: reagent concentrations at reverse transcription stage affect the PCR performance. J. Virol. Methods 86: 121-129.

Strange, R. N. 2005. Plant disease: a threat to global food security. Annu. Rev. Phytopathol. 43: 83-116.

Su, C. C., Wu, T. Z., Chen, L. K., Yang, H. H. and Tai, D. F. 2003. Development of immunochips for the detection of dengue viral antigens. Anal. Chim. Acta 479: 117-123.

Sun, W., Jiao, K., Zhang, S., Zhang, C. and Zhang, Z. 2001. Electrochemical detection for horseradish peroxidase-based enzyme immunoassay using $p$-aminophenol as substrate and its application in detection of plant virus. Anal. Chim. Acta 434: 43-50.

Susmel, S., O'Sullivan, C. K. and Guilbault, G. G. 2000. Human cytomegalovirus detection by a quartz crystal microbalance immunosensor. Enzyme Microb. Tech. 27: 639-645.

Tang, D.-Q., Zhang, D.-J., Tang, D.-Y. and Ai, H. 2006. Amplification of the antigen-antibody interaction from quartz crystal microbal- 
ance immunosensors via back-filling immobilization of nanogold on biorecognition surface. J. Immunol. Methods 316: 144152.

Tomita, N., Mori, Y., Kanda, H. and Notomi, T. 2008. Loop-mediated isothermal amplification (LAMP) of gene sequences and simple visual detection of product. Nature Protoc. 3: 877-882.

Tomlinson, J. A., Boonham, N. and Dickinson, M. 2010. Development and evaluation of a one-hour DNA extraction and loopmediated isothermal amplification assay for rapid detection of phytoplasmas. Plant Pathol. 59: 465-471.

Torrance, L. 1998. Developments in serological methods to detect and identify plant viruses. Plant Cell Tiss. Org. Cult. 52: 27-32.

Uttenthaler, E., Schraml, M., Mandel, J. and Drost, S. 2001. Ultrasensitive quartz crystal microbalance sensors for detection of M13Phages in liquids. Biosens. Bioelectron. 16: 735-743.

van der Want, J. P. H. and Dijkstra, J. 2006. A history of plant virology. Arch. Virol. 151:1467-1498.

Vaskova, D., Spak, J., Klerks, M. M., Schoen, C. D., Thompson, J. R. and Jelkmann, W. 2004. Real-time NASBA for detection of Strawberry vein banding virus. Eur. J. Plant Pathol. 110: 213-221.

Vemulapati, B., Druffel, K. L., Husebye, D., Eigenbrode, S. D. and Pappu, H. R. 2014. Development and application of ELISA assays for the detection of two members of the family Luteoviridae infecting legumes: Pea enation mosaic virus (genus Enamovirus) and Bean leafroll virus (genus Luteovirus). Annu. Appl. Biol. 165: 130-136.

Vidaver, A. K. and Lambrecht, P. A. 2004. Bacteria as plant pathogens. The Plant Health Instructor. www.apsnet.org/.../PathogenGroups/Pages/B acteria.aspx (Accessed Jul. 20, 2014).

Wang, B., Ma, Y., Zhang, Z., Wu, Z., Wu, Y., Wanga, Q. and Li, M. 2011.
Potato viruses in China. Crop Protect. 30: 1117-1123.

Wang, D., Coscoy, L., Zylberberg, M., Avila, P. C., Boushey, H. A. and Ganem, D. 2002. Microarray-based detection and genotyping of viral pathogens. Proc. Natl. Acad. Sci. 99: 15687-15692.

Wang, D., Urisman, A., Liu, Y. T., Springer, M., Ksiazek, T. G., Erdman, D. D., Mardis, E. R., Hickenbotham, M., Magrini, V., Eldred, J., Latreille, J. P., Wilson, R. K., Ganem, D. and DeRisi, J. L. 2003. Viral discovery and sequence recovery using DNA microarrays. PLoS Biol. 1: 257-260.

Webster, C. G., Wylie, J. S. and Jones, M. G. K., 2004. Diagnosis of plant viral pathogens. Curr. Sci. 86: 1604-1607.

Yang, J.-G., Wang, F.-L., Chen, D.-X., Shen, L.-L., Qian, Y.-M., Liang, J. Y., Zhou, W.-C. and Yan, T.-H. 2012. Development of a one-step immunocapture real-time RT-PCR assay for detection of Tobacco Mosaic Virus in Soil. Sensors 12: 16685-16694.

Yardimci, B. C. N. and Culal-KIllc, H. 2011. Detection of viruses infecting stone fruits in Western mediterranean region of Turkey. Plant Pathology J. 27: 44-52.

Zan, X., Sitasuwana, P., Powellb, J., Dreherb, T. W. and Wang, Q. 2012. Polyvalent display of RGD motifs on Turnip yellow mosaic virus for enhanced stem cell adhesion and spreading. Acta Biomater. 8: 2978-2985.

Zhang, Y., Yin, J., Li, G., Li, M., Huang, X., Chen, H., Zhao, W. and Zhu, S. 2010. Oligonucleotide microarray with a minimal number of probes for the detection and identification of thirteen genera of plant viruses. J. Virol. Methods 167: 53-60. 